\title{
Pengaruh Pemberian PMT Bubuk Koya Berbahan Dasar Udang Rebon (Mysis relicta) terhadap Perubahan Kadar Hemoglobin Ibu Hamil
}

\author{
Vera Iriani Abdullah ${ }^{1^{*}}$, Mariana Isir $^{2}$ \\ ${ }^{1 *}, 2$ Jurusan Kebidanan Poltekkes Kemenkes Sorong \\ * corresponding author \\ Vera Iriani Abdullah \\ Poltekkes Kemenkes Sorong \\ verabdullah1977@gmail.com
}

\begin{abstract}
Abstrak
Anemia dalam kehamilan yaitu kadar $\mathrm{Hb}$ kurang dari $11 \mathrm{~g} / \mathrm{dL}$ atau hematokrit, 33\%, sampai saat ini masih menjadi masalah kesehatan global, yang mempengaruhi hampir $50 \%$ wanita hamil, sekaligus faktor penyebab terjadinya morbiditas pada janin dan ibu. Penangganan anemia dilakukan dengan pemberian tablet zat besi yang dimulai pada awal kehamilan, sesuai rekomendasi WHO. Namun selain asupan tablet tambah darah diperlukan juga tambahan asupan micronutrient dengan pemberian suplementasi makanan yang mengandung zat besi. Salah satu bahan pangan hewani yang memenuhi multi micronutrient termasuk didalamya zat besi yaitu udang rebon karena ini merupakan suplementasi zat besi yang sumber dari pangan hewani sehingga lebih mudah diserap oleh tubuh. Tujuan penelitian ini untuk menganalisis perbedaan kadar hemoglobin ibu hamil sebelum dan sesudah mengkonsumsi PMT bubuk koya berbahan dasar udang rebon pada kelompok intervensi dan kontrol. Jenis penelitian ini adalah penelitian kuantitatif dengan metode quasi eksperimen menggunakan pendekatan posttest control group design. Hasil penelitian menunjukkan nilai p $0.000<0,05$, artinya terdapat perbedaan yang bermakna antara kelompok kontrol dan kelompok intervensi. Kesimpulan terdapat pengaruh konsumsi PMT bubuk koya berbahan dasar udang rebon (Mysis relicta) terhadap perubahan kadar hemoglobin ibu hamil.
\end{abstract}

Kata Kunci: Udang Rebon; Hemoglobin; Kehamilan

\section{The Effect of Giving PMT Koya Powder Made from Rebon Shrimp (Mysis relicta) on Change Hemoglobin Levels of Pregnant Women}

\begin{abstract}
Anemia in pregnancy, namely an Hb level of less than $11 \mathrm{~g} / \mathrm{dL}$ or hematocrit, 33\%, is still a global health problem, affecting nearly $50 \%$ of pregnant women, as well as a contributing factor to fetal and maternal morbidity. Iron tablets started early in pregnancy, according to WHO recommendations. However, in addition to the intake of bloodsupplemented tablets, additional micronutrient intake is also needed by providing supplementation with foods containing iron. One of the animal food ingredients that meet multi micronutrients including iron, namely rebon shrimp because this is iron supplementation which is a source of animal food so that it is easier to absorb by the
\end{abstract}


Pengaruh Pemberian PMT Bubuk Koya Berbahan Dasar Udang Rebon (Mysis relicta) terhadap Perubahan Kadar Hemoglobin Ibu Hamil

body. The purpose of this study was to analyze the differences in hemoglobin levels of pregnant women before and ingesting PMT koya powder made from rebon shrimp in the intervention and control groups. This type of research is a quantitative study with a quasiexperimental method using a posttest control group design approach. The results showed a $p$ value of $0.000<0.05$, which is a significant difference between the control group and the intervention group. Conclusion the effect of PMT consumption of koya powder made from rebon shrimp on changes in hemoglobin levels of pregnant women.

Keywords: Rebon Shrimp; Hemoglobin; Pregnancy

Pendahuluan

Anemia dalam kehamilan, merupakan masalah kesehatan global, yang mempengaruhi hampir $50 \%$ wanita hamil, sekaligus sebagai salah satu faktor penyebab terjadinya morbiditas pada janin dan ibu. Defisiensi zat besi, kobalamin, dan asam folat merupakan faktor pencetus yang paling sering menyebabkan anemia pada kehamilan. Kekurangan zat besi dapat menyebabkan terhambatnya perkembangan, kelainan kognitif, cacat tabung saraf, kelahiran prematur, berat badan lahir rendah (BBLR), dan bayi baru lahir dengan usia kecil menurut gestasi (SGA). Beberapa bukti menunjukkan kekurangan zat besi pada trimester ke-3, dapat mempengaruhi perkembangan saraf pada janin hingga usia remaja dan dewasa yang berorientasi pada prestasi akademik (Janbek et al. 2019).
Organisasi kesehatan dunia (WHO) mendefinisikan anemia kehamilan yaitu kadar $\mathrm{Hb}$ kurang dari $11 \mathrm{~g} / \mathrm{dL}$ atau hematokrit 33\%, selama kehamilan tanpa memandang usia kehamilan (Achebe and Gafter-Gvili 2017). Penangganan anemia salah satunya dengan pemberian tablet zat besi secara oral yang dimulai pada awal kehamilan, sesuai rekomendasi WHO (Achebe and Gafter-Gvili 2017).

Walaupun demikian namun sampai saat ini angka kejadian anemia masih sangat tinggi, untuk itu selain asupan tablet tambah darah diperlukan juga tambahan asupan micronutrient, menurut Azam et al., (2017) yang dikutip dalam Abdullah and Haumahu (2020) bahwa selain pemberian tablet zat besi, pada ibu hamil juga harus diberikan suplementasi makanan yang mengandung zat besi. Salah satu bahan pangan hewani yang 
Pengaruh Pemberian PMT Bubuk Koya Berbahan Dasar Udang Rebon (Mysis relicta) terhadap Perubahan Kadar Hemoglobin Ibu Hamil

memenuhi multi micronutrient termasuk didalamya zat besi yaitu udang rebon, karena dalam $100 \mathrm{gr}$ udang rebon kering mengandung 295 kal kalori, 62,4 g protein, 2,3 g lemak, $1,8 \mathrm{gr}$ karbohidrat, $1209 \mathrm{mg}$ kalsium, $1225 \mathrm{mg}$ fosfor, $6,3 \mathrm{mg}$ zat besi, vit A $210 \mathrm{mg}, 0,14 \mathrm{mg}$ vit $\mathrm{B} 1,20,7 \mathrm{~g}$ air (Syarif et al. 2017).

Suplementasi zat besi yang bersumber dari pangan hewani lebih mudah diserap oleh tubuh sekitar 20$30 \%$ dibandingkan dengan pangan yang berasal dari nabati (Kementerian Kesehatan, 2019).

Tujuan penelitian ini untuk menganalisis perbedaan kadar hemoglobin ibu hamil sebelum dan sesudah mengkonsumsi PMT bubuk koya berbahan dasar udang rebon pada kelompok intervensi dan kontrol. Tingginya kasus anemia pada ibu hamil dan pentingnya penangganan masalah ini maka peneliti ingin menggali potensi sumber daya laut Papua, untuk dapat dijadikan alternatif pangan dalam penanganan anemia, selain itu dengan adanya penelitian ini dapat memperkenalkan udang rebon secara luas pada masyarakat agar dapat membantu peningkatan hasil nelayan.
Hal ini sejalan dengan penelitian yang dilakukan di Bangladesh, menunjukkan bahwa status sosial ekonomi dan profitabilitas finansial dari budidaya udang rebon di pesisir, dapat memberikan keuntungan sehingga mampu menopang status ekonomi masyarakat (Shawon et al. 2018). Untuk itu peneliti mengangkat penelitian ini agar memberikan kontribusi selain pada bidang kesehatan juga pada bidang ekonomi.

\section{Metode}

Jenis penelitian ini adalah penelitian kuantitatif dengan metode quasi eksperimen menggunakan pendekatan posttest control group design (Suwarjana, 2015). Tempat penelitian dilakukan pada 2 wilayah kerja yaitu Puskesmas Sorong Barat Kota Sorong dan Puskesmas Malawili Kabupaten Sorong Propinsi Papua Barat. Waktu pelaksanaan pengumpulan data selama 1,5 bulan. Populasi seluruh ibu hamil di wilayah kerja Puskesmas Sorong Barat dan Puskesmas Malawili. Sampel penelitian sebanyak 30 orang yang dibagi dalam kelompok intervensi sebanyak 15 orang dan kelompok control 15 orang, teknik sampel 
Pengaruh Pemberian PMT Bubuk Koya Berbahan Dasar Udang Rebon (Mysis relicta) terhadap Perubahan Kadar Hemoglobin Ibu Hamil

menggunakan teknik purposive sampling. Kelompok intervensi diberikan bubuk koya sebanyak 100 gram/hari selama 7 hari, dengan asumsi untuk pemenuhan $70 \mathrm{KKal}$, sedangkan grup kontrol dianjurkan untuk makan makanan seperti pola konsumsi sehari-hari. Tablet SF pada kelompok intervensi dan kontrol tetap dilanjutkan sesuai jadwal. Analisis data menggunakan uji paired samples test, yang bertujuan untuk menganalisis perbedaan sebelum dan sesudah perlakuan.

\section{Hasil dan Pembahasan}

Hasil

Analisis univariat dilakukan untuk menganalisis variabel dari hasil penelitian, serta berfungsi untuk meringkas kumpulan data hasil pengukuran.

Tabel 1. Karakteristik Responden

\begin{tabular}{lcccc}
\hline \multirow{2}{*}{ Variabel } & \multicolumn{4}{c}{ Kelompok } \\
\cline { 2 - 5 } & $\begin{array}{c}\text { Intervensi } \\
(\mathrm{n}=15)\end{array}$ & $\begin{array}{c}\text { Kontrol } \\
(\mathrm{n}=15)\end{array}$ \\
\cline { 2 - 5 } Usia & $\mathrm{n}$ & $\%$ & $\mathrm{n}$ & $\%$ \\
$<20$ & 1 & 6,6 & 1 & 6,6 \\
$20-35$ & 14 & 93,3 & 13 & 86,6 \\
$>35$ & 0 & 0 & 1 & 6,6 \\
\hline Total & $\mathbf{1 5}$ & $\mathbf{1 0 0}$ & $\mathbf{1 5}$ & $\mathbf{1 0 0}$ \\
\hline Agama & & & & \\
Islam & 15 & 100 & 11 & 73,3 \\
Kristen Protestan & 0 & 0 & 3 & 20 \\
Kristen Katolik & 0 & 0 & 1 & 6,6 \\
\hline Total & $\mathbf{1 5}$ & $\mathbf{1 0 0}$ & $\mathbf{1 2}$ & $\mathbf{1 0 0}$ \\
\hline Pekerjaan & & & & \\
IRT & 15 & 100 & 15 & 100 \\
Non IRT & 0 & 0 & 0 & 0 \\
\hline Total & $\mathbf{1 5}$ & $\mathbf{1 0 0}$ & $\mathbf{1 5}$ & $\mathbf{1 0 0}$ \\
\hline
\end{tabular}

\begin{tabular}{lcccc}
\hline Paritas & 3 & 20 & 5 & 33,3 \\
1 & 12 & 80 & 10 & 66,6 \\
$2-5$ & 0 & 0 & 0 & 0 \\
$>5$ & 15 & $\mathbf{1 0 0}$ & $\mathbf{1 5}$ & $\mathbf{1 0 0}$ \\
\hline Total & & & & \\
\hline Usia Kehamilan & 3 & 20 & 1 & 6,6 \\
1-13 minggu & 4 & 26,6 & 7 & 46,6 \\
14-26 minggu & 8 & 53,3 & 7 & 46,6 \\
27-40 minggu & $\mathbf{1 5}$ & $\mathbf{1 0 0}$ & $\mathbf{1 5}$ & $\mathbf{1 0 0}$ \\
\hline Total & tabel &
\end{tabular}

menunjukkan bahwa karakteristik responden berdasarkan usia pada kelompok intervensi dan kontrol terbanyak pada usia 20-35 tahun, pada kelompok intervensi sebanyak 14 responden (93,3\%) sedangkan pada kelompok kontrol sebanyak 13 responden (86,6\%). Pada karakteristik responden berdasarkan agama baik kelompok intervensi maupun kontrol terbanyak beragama Islam, pada kelompok intervensi sebanyak 15 responden (73,3\%) sedangkan kelompok kontrol sebanyak 11 responden (73,3\%).

Pada karakteristik responden berdasarkan pekerjaan pada kedua kelompok sebanyak 30 Responden (100\%) ibu rumah tangga. Karakteristik responden berdasarkan paritas pada kelompok intervensi dan kontrol terbanyak pada kelompok 2-5 anak atau multigravida. Kelompok intervensi sebanyak 12 responden (80\%), sedangkan pada kelompok kontrol sebanyak 10 responden $(66,6 \%)$. 
Pengaruh Pemberian PMT Bubuk Koya Berbahan Dasar Udang Rebon (Mysis relicta) terhadap Perubahan Kadar Hemoglobin Ibu Hamil

Karakteristik responden

berdasarkan usia kehamilan pada kelompok intervensi terbanyak pada kelompok usia kehamilan pada trimester 2 berkisar pada usia kehamilan 27-40 minggu sebanyak 8 responden (53,3\%). Sedangkan pada kelompok kontrol terbanyak pada usia kehamilan trimester 2 dan 3 masing-masing sebanyak 7 responden (46,6\%).

Tabel 2. Kadar $\mathrm{Hb}$ Sebelum dan Sesudah Intervensi

\begin{tabular}{lrrrrrrrrr}
\hline Kategori & \multicolumn{3}{c}{ Intervensi } & \multicolumn{4}{c}{ Kontrol } \\
\cline { 2 - 9 } & \multicolumn{2}{c}{ Pre } & \multicolumn{1}{c}{ Post } & \multicolumn{2}{c}{ Pre } & \multicolumn{3}{c}{ Post } \\
\cline { 2 - 9 } & $\mathrm{n}$ & $\%$ & $\mathrm{n}$ & $\%$ & $\mathrm{n}$ & $\%$ & \multicolumn{2}{c}{$\mathrm{n}$} & $\%$ \\
\hline $\begin{array}{l}\text { Hemoglobin } \\
<10,5\end{array}$ & 7 & 46,6 & 6 & 40 & 1 & 6,6 & 4 & 26,6 \\
$\mathrm{~g} / \mathrm{dl}$ \\
$\begin{array}{l}>10,5 \\
\mathrm{~g} / \mathrm{dl})\end{array}$ & 8 & 53,3 & 9 & 60 & 14 & 93,3 & 11 & 73,3 \\
\hline Total & 15 & 100 & 15 & 100 & 15 & 100 & 15 & 100 \\
\hline \multicolumn{4}{c}{ Berdasarkan } & uraian & tabel & 2
\end{tabular}
menunjukkan bahwa pada kelompok intervensi untuk kadar hemoglobin sebelum dan sesudah diberikan intervensi terbanyak pada kategori normal dengan kisaran > 10,5 g/dl sebanyak 8 responden (53,3\%) dan setelah diberikan intervensi sebanyak 9 responden (60\%).

Tabel 3. Rerata Hasil Pengukuran Kadar Hemoglobin Sebelum dan Sesudah Intervensi

\begin{tabular}{lcc}
\hline & \multicolumn{2}{c}{ Mean \pm Std.Deviasi } \\
\cline { 2 - 3 } Kelompok & Awal & Akhir \\
\cline { 2 - 3 } & $\mathbf{H b}$ & $\mathbf{H b}$ \\
\hline Intervensi & $10.453 \pm 1.8189$ & $5.867 \pm 0.5948$ \\
Kontrol & $11.513 \pm 1.1575$ & $7.113 \pm 1.1904$ \\
\hline \multicolumn{1}{c}{ Hasil } & rerata terdapat & perubahan
\end{tabular}

kadar $\mathrm{Hb}$ ibu hamil pada kelompok kontrol lebih kecil dari kelompok pemberian intervensi. Setelah itu akan dilakukan uji univariat dengan uji paired samples test. Namun sebelumnya akan dilakukan uji normalitas menggunakan ShapiroWilk karena sampel data pada masing-masing kelompok kurang dari 50 sampel. Jika didapatkan $p>0,05$ maka data berdistribusi normal. Hasil uji normalitas dapat dilihat pada tabel 6 dibawah ini:

Tabel 4. Hasil Uji Normalitas Univariat

\begin{tabular}{|c|c|c|c|}
\hline & Data & Sig & Ket \\
\hline \multirow[t]{2}{*}{$\begin{array}{l}\text { Test o } \\
\text { normality }\end{array}$} & $\begin{array}{l}\text { Kelompok } \\
\text { Intervensi } \\
\text { HB Pre }\end{array}$ & 0,323 & $\begin{array}{l}\text { Data } \\
\text { berditribusi } \\
\text { normal }\end{array}$ \\
\hline & $\begin{array}{l}\text { Kelompok } \\
\text { Intervensi } \\
\text { HB Post }\end{array}$ & 0,155 & $\begin{array}{l}\text { Data } \\
\text { berditribusi } \\
\text { normal }\end{array}$ \\
\hline
\end{tabular}

berdistribusi normal. Setelah uji normalitas akan dilakukan uji paired samples test, bertujuan untuk menganalisis perbedaan sebelum dan sesudah perlakuan, Jika didapatkan $\mathrm{p}<0,05$ maka terdapat perbedaan yang bermakna.

Tabel 5. Hasil Uji Univariat Menggunakan Paired Samples Test dan Wilcoxon

\begin{tabular}{llll}
\hline & Data & Sig & Ket \\
\hline Paired & HB Pre & 0,002 & Terdapat \\
Samples & Dan Post & & perbedaan \\
Test dan & Kelompok & & yang \\
Wilcoxon & Intervensi & & bermakna \\
\cline { 2 - 4 } & HB pre & 0,002 & Terdapat \\
& Dan Post & & perbedaan \\
& Kelompok & & yang \\
& Kontrol & & bermakna \\
\hline
\end{tabular}

Hasil uji paired samples test

dan Wilcoxon, menunjukkan kadar $\mathrm{Hb}$ mengalami perbedaan yang bermakna. 
Pengaruh Pemberian PMT Bubuk Koya Berbahan Dasar Udang Rebon (Mysis relicta) terhadap Perubahan Kadar Hemoglobin Ibu Hamil

Analisis bivariat untuk membuktikan perbedaan kadar $\mathrm{Hb}$ pre dan post intervensi dilakukan uji bivariat menggunakan uji independent samples test. Pengujian normalitas data diperlukan untuk memenuhi syarat uji independent samples test.

Tabel 6. Hasil Uji Normalitas Bivariat Menggunakan Kolmogorov Smirnov Z

\begin{tabular}{llll}
\hline \multicolumn{2}{c}{ Kelompok } & Sig & Keterangan \\
\hline $\begin{array}{l}\text { Test of } \\
\text { normality }\end{array}$ & Intervensi & 0.000 & $\begin{array}{l}\text { tidak } \\
\text { berdistribusi } \\
\text { normal }\end{array}$ \\
\cline { 2 - 4 } & Kontrol & 0.000 & $\begin{array}{l}\text { tidak } \\
\text { berdistribusi } \\
\text { normal }\end{array}$ \\
\hline
\end{tabular}

Dari tabel 6 di atas didapatkan

data tidak berdistribusi normal. Setelah itu, dilakukan uji homogenitas dengan uji Levene untuk melihat varians data yang homogen atau tidak. Hasil uji homogenitas varian data tidak homogen. Data tidak berdistribusi normal dan tidak homogen sehingga tidak dapat dilakukan uji independent sample test. Hasil uji homogenitas dan normalitas memenuhi syarat uji Mann Whitnney. Hasil uji Levene test dan Mann Whitnney sebagai berikut:

Tabel 7. Hasil Uji Homogenitas Menggunakan Levene Test

\begin{tabular}{lcc}
\hline \multicolumn{1}{c}{ Levene's test } & Sig & Ket \\
\hline Perbandingan & 0.057 & $\begin{array}{c}\text { Varians data } \\
\text { homogen }\end{array}$ \\
Konsumsi Bubuk & & \\
Koya dan & & \\
Pendidikan & & \\
Kesehatan Pola & & \\
Makan Harian & & \\
\hline
\end{tabular}

Tabel 8. Hasil Uji Perbandingan Perubahan Menggunakan Mann Whitnney

\begin{tabular}{lcl}
\hline Mann Whitnney & Sig & \multicolumn{1}{c}{ Ket } \\
\hline Perbandingan & 0.000 & Terdapat \\
perubahan antara & & perbedaan \\
Kelompok Kontrol & & yang \\
dan Intervensi & & bermakna \\
\hline
\end{tabular}

Dari tabel 7 didapatkan varian

data homogen yang berarti semua syarat terpenuhi. Setelah itu, dilakukan uji Mann Whitnney dengan hasil pada tabel 8 didapatkan hasil nilai p $0.000<0,05$, artinya terdapat perbedaan yang bermakna antara kelompok kontrol dan kelompok intervensi.

\section{Pembahasan}

Karakteristik pada kelompok usia responden, baik kelompok intervensi dan kontrol, terbanyak pada usia 20-35 tahun, ini merupakan usia kehamilan dan persalinan yang aman karena pada usia ini ibu sudah siap secara fisik dan mental untuk menghadapi kehamilan dan persalinan selain itu resiko terjadinya anemia sangat rendah.

Sebuah penelitian yang dilakukan oleh Zahidatul (2017) menunjukkan bahwa ibu hamil yang berumur $<20$ tahun memiliki resiko mengalami anemia 2,250 kali lebih besar dan usia > 35 tahun memiliki resiko mengalami anemia 5,885 kali lebih besar dibandingkan dengan usia 20-35 tahun. Namun hal ini tidak 
Pengaruh Pemberian PMT Bubuk Koya Berbahan Dasar Udang Rebon (Mysis relicta) terhadap Perubahan Kadar Hemoglobin Ibu Hamil

sejalan dengan data yang di dapatkan dimana masih ada responden yang memikili kadar hemoglobin rendah $<10,5 \mathrm{~g} / \mathrm{dl}$, walaupun presentasinya di bawah 50\% (Zahidatul Rizkah dan Trias Mahmudiono, 2017).

Responden pada kedua kelompok $100 \%$ tidak bekerja artinya bahwa ibu menjalankan kewajiban sehari-hari sebagai ibu rumah tangga, kelompok ibu yang tidak bekerja merupakan kelompok yang rentan menderita anemia, di mana data menujukkan bahwa ibu yang tidak bekerja memiliki kemungkinan 1,990 lebih besar mengalami anemia dibandingkan dengan ibu hamil yang bekerja. ibu yang tidak bekerja harus melakukan kerja keras selama kehamilan untuk mencukupi kebutuhannya selain itu kelompok ini cenderung memiliki status sosial ekonomi yang lebih rendah sehingga kebutuhan nutrisi tidak tercukupi (Zahidatul Rizkah Dan Trias Mahmudiono, 2017).

Paritas responden terbanyak pada multipara, perempuan yang sering mengalami kehamilan dan melahirkan cenderung akan lebih mengalami anemia. Hal ini disebabkan karena selama kehamilan wanita menggunakan cadangan besi yang ada di dalam tubuhnya untuk pembentukan janin dan persalinan (Astriana 2017).

Reponden pada kelompok intervensi dan kontrol terbanyak memeluk agama Islam. Agama merupakan salah satu faktor penyumbang terjadinya anemia pada ibu hamil. Hal ini sesuai teori yang menunjukkan bahwa faktor sosial budaya seperti buta huruf, kemiskinan, kurangnya kesadaran, tabu budaya dan agama, kemiskinan kebiasaan makan, dan prevalensi infestasi parasit yang tinggi merupakan faktor pendukung terjadinya anemia (Gebre and Mulugeta 2015).

Usia kehamilan memegang peranan yang cukup penting dalam kejadian anemia, karena pada masa ini volume darah akan bersirkulasi secara bertahap dan progresif mulai usia kehamilan 10 minggu dan akan mencapai puncaknya pada umur kehamilan 32-36 minggu. Perbandingan pertambahan komponen darah yaitu plasma $30 \%$, sel darah $18 \%$ dan hemoglobin $19 \%$. Pertambahan ini tidak sebanding antara komponen plasma darah dan sel-sel darah, sehingga darah 
Pengaruh Pemberian PMT Bubuk Koya Berbahan Dasar Udang Rebon (Mysis relicta) terhadap Perubahan Kadar Hemoglobin Ibu Hamil

menjadi encer dan dapat menyebabkan terjadinya anemia (Ramadhanti, 2018).

Perbedaaan signifikan antara ibu yang diberikan bubuk koya udang rebon dengan ibu yang hanya diberikan edukasi untuk makan sesuai pola makan harian. Pemberian bubuk koya udang rebon mampu memenuhi $70 \mathrm{KKal}$, dengan komposisi kandungan kalsium (Ca) sebanyak $41 \mathrm{mg}$, protein sebanyak $265 \mathrm{mg}$, Fe sebanyak 21,4 mg, vitamin B1 sebanyak $0.06 \mathrm{mg}$ dan air sebanyak 21,6 gram.

Kandungan protein dalam tubuh berfungsi sebagai alat transportasi zat besi. Konsumsi makanan tinggi protein dapat meningkatkan kadar hemoglobin. Hal ini sejalan dengan penelitian yang dilakukan di Kabupaten Sorong, 2019, menunjukkan bahwa wanita usia subur yang mengkonsumsi biskuit kerang secara signifikan dapat meningkatkan kadar hemoglobin karena kerang kaya akan protein (Abdullah and Haumahu, 2020).

Sebuah penelitian yang dilakukan pada Rumah Sakit Gambella, Southwest Ethiopia dari bulan Januari sampai Maret 2016, dengan melibatkan 246 wanita hamil menunjukkan bahwa kadar $\mathrm{Hb}$ yang rendah dikaitkan erat dengan kekurangan zink, sebagai dampak kurangnya konsumsi makanan dari sumber hewani dan ketidakragaman lauk saat makan pada ibu hamil. (Begum et al. 2019). Hal ini memiliki efek buruk pada ibu dan janin hingga dapat mengakibatkan peningkatan morbiditas (Mekonnen et al., 2019).

Ibu hamil yang kekurangan zink dapat menyebabkan hipertensi gestasional, cacat pada saraf janin, ketuban pecah dini, berat badan lahir rendah, perkembangan perilaku saraf yang buruk, gangguan kognitif, retardasi pertumbuhan intrauterin, gangguan toleransi glukosa, malformasi kongenital, lahir mati, prematur persalinan, perdarahan pascapartum, persalinan lama, kontraksi uterus yang tidak adekuat, kelainan pada replikasi gen, keterlambatan perkembangan sistem kekebalan yang menyebabkan peningkatan morbiditas dan mortalitas neonatal (Mekonnen et al., 2019).

Kegagalan pertumbuhan linier adalah bentuk kekurangan gizi yang paling umum secara global. Dengan perkiraan 165 juta anak di bawah usia 5 tahun yang terkena dampak, 
Pengaruh Pemberian PMT Bubuk Koya Berbahan Dasar Udang Rebon (Mysis relicta) terhadap Perubahan Kadar Hemoglobin Ibu Hamil

stunting telah diidentifikasi sebagai prioritas utama kesehatan masyarakat, dan ada target ambisius untuk mengurangi prevalensi stunting sebesar $40 \%$ antara tahun 2010 dan 2025. Kondisi ini dipandang sebagai 'sindrom stunting' di mana beberapa perubahan patologis yang ditandai dengan penurunan pertumbuhan linier di awal kehidupan dikaitkan dengan peningkatan morbiditas dan mortalitas, penurunan kapasitas fisik, perkembangan saraf dan ekonomi dan peningkatan risiko penyakit metabolik hingga dewasa, cenderung memiliki keturunan yang terbengkalai, menciptakan siklus kemiskinan antargenerasi dan berkurangnya sumber daya manusia yang sulit diputus (Prendergast and Humphrey 2014).

\section{Defisiensi}

micronutrient merupakan salah satu faktor pencetus terjadinya anemia. Pada masa antenatal pertumbuhan janin diatur oleh interaksi kompleks dari status gizi ibu, sinyal endokrin dan metabolik, serta perkembangan plasenta (Prendergast and Humphrey, 2014).

Secara global, seperlima wanita hamil mengalami anemia defisiensi besi selama kehamilan, ini juga dapat berdampak terjadinya stunting sehingga menyebabkan terganggunya perkembangan kognitif, motorik, dan sosial-ekonomi yang buruk. Sebuah meta-analisis menunjukkan bahwa anemia selama trimester pertama atau kedua meningkat risiko prematuritas dan berat lahir rendah.

WHO merekomendasikan 60 $\mathrm{mg}$ zat besi setiap hari selama kehamilan, namun sebuah uji coba terkontrol secara acak di Bangladesh menunjukkan bahwa pemberian zat besi yang ditambahkan dengan asupan multiple micronutrients berdampak pada panjang badan anak sedikit lebih saat lahir, bulan pertama, ketiga dan bulan keenam (Haider et al., 2013).

Dengan demikian maka pemberian tambahan micronutrient dengan tablet zat besi pada ibu hamil akan lebih memberikan dampak positif terhadap pada bayi yang dilahirkan.

\section{Simpulan}

Hipotesis nol ditolak dengan demikian terdapat pengaruh konsumsi PMT bubuk koya berbahan dasar udang rebon (Mysis relicta) 
Pengaruh Pemberian PMT Bubuk Koya Berbahan Dasar Udang Rebon (Mysis relicta) terhadap Perubahan Kadar Hemoglobin Ibu Hamil

terhadap perubahan kadar

hemoglobin ibu hamil.

\section{Daftar Pustaka}

Abdullah, Vera Iriani, and C. .. Haumahu. 2020. "Pengaruh Konsumsi Cookies Kerang Dara (Anadara Granosa) Terhadap Perubahan Kadar Haemoglobin Wanita Usia Subur." Journal of Holistic Nursing Science 7(2):169-79.

Achebe, Maureen M., and Anat Gafter-Gvili. 2017. "How I Treat Anemia in Pregnancy: Iron, Cobalamin, and Folate." Blood 129(8):940-49.

Astriana, Willy. 2017. "Kejadian Anemia Pada Ibu Hamil Ditinjau Dari Paritas Dan Usia." Jurnal Aisyah: Jurnal IImu Kesehatan 2(2):123-30.

Begum, Taslima, Md Anwar Habib, Shipra Chaudhury, Hasina Akter, Tahmida Firdousi, Fahmida Hafez, Nur Mohammad, and ABM Ruhul Amin. 2019. "Association of Serum Albumin Level in Predicting of Preeclampsia among Pregnant Women in Dhaka City of Bangladesh." Journal of Current and Advance Medical Research 6(2):83-86.

Gebre, Abel, and Afework Mulugeta. 2015. "Prevalence of Anemia and Associated Factors among Pregnant Women in North Western Zone of Tigray, Northern Ethiopia: A CrossSectional Study." Journal of Nutrition and Metabolism 2015.

Haider, Batool A., Ibironke Olofin, Molin Wang, Donna Spiegelman,
Majid Ezzati, and Wafaie W. Fawzi. 2013. "Anaemia, Prenatal Iron Use, and Risk of Adverse Pregnancy Outcomes: Systematic Review and MetaAnalysis." BMJ (Online) 347(7916).

Janbek, Janet, Mahesh Sarki, Ina O. Specht, and Berit L. Heitmann. 2019. "A Systematic Literature Review of the Relation between Iron Status/Anemia in Pregnancy and Offspring Neurodevelopment." European Journal of Clinical Nutrition 73(12):1561-78.

Kementerian Kesehatan RI. 2019. "Aksi Bergizi, Hidup Sehat Sejak Sekarang Untuk Remaja Kekinian." Kementrian Kesehatan Republik Indonesia 214.

Mekonnen, Ataguade, Wondwossen Terefe, Abate Bekele Belachew, Amaha Kahsay Adhanu, and Kebede Embaye Gezae. 2019. "Prevalence and Associated Factors of Zinc Deficiency Among Pregnant Women Attending Antenatal Care at Gambella Hospital, Gambella, Ethiopia, 2018." American Journal of Life Sciences 7(5):91.

Prendergast, Andrew J., and Jean $\mathrm{H}$. Humphrey. 2014. "The Stunting Syndrome in Developing Countries." Paediatrics and International Child Health 34(4):250-65.

Ramadhanti. 2018. Faktor-Faktor Yang Mempengaruhi Kejadian Anemia Pada Ibu Hamil Di Puskesmas Tegalrejo. International Journal of Machine Tools and Manufacture 5(1):8696. 
Pengaruh Pemberian PMT Bubuk Koya Berbahan Dasar Udang Rebon (Mysis relicta) terhadap Perubahan Kadar Hemoglobin Ibu Hamil

Shawon, Noor A. Arefin, Md Masudul Haque Prodhan, Md

Akhtaruzzaman Khan, and Sandip Mitra. 2018. "Financial Profitability of Small Scale Shrimp Farming in a Coastal Area of Bangladesh." Journal of the Bangladesh Agricultural University 16(1):104-10.

Suwarjana, I. Ketut. n.d. Metodologi Penelitian Kesehatan. Edisi Revi. Yogyakarta: Andi Offset.

Syarif, Wirnelis, Rahmi Holinesti, Anni Faridah, and Lucy Fridayati. 2017. "Analisis Kualitas Sala Udang Rebon." Jurnal Teknologi Pertanian Andalas 21(1):45.

Zahidatul Rizkah, and Trias Mahmudiono. 2017. "Hubungan Antara Umur, Gravida, Dan Status Bekerja Terhadap Resiko Kurang Energi Kronis (KEK) Dan Anemia Pada Ibu Hamil." Amerta Nutrition 1(2):72-79. 